\title{
THE EFFECT OF USING PUPPET SHOW STRATEGY ON STUDENTS' READING COMPREHENSION
}

\author{
Annesa J. Retami \\ State Islamic University Sultan Syarif Kasim of Riau, Indonesia \\ annesa.j.retami@students.uin-suska.ac.id \\ M. Syafi'I S \\ State Islamic University of Sultan Syarif Kasim Riau, Indonesia \\ m.syafii.S@uin-suska.ac.id \\ Khairunnas Syafii \\ State Islamic University Sultan Syarif Kasim of Riau, Indonesia \\ khairunnas@uin-suska.ac.id
}

\begin{abstract}
This was aimed at investigating the effect of using Puppet Show strategy on students reading comprehension of narrative texts. The design of this research was quasi experimental design. The population and sample participated was the eighth grade students at Islamic Junior High School AlMuttaqin Pekanbaru. The number of sampling was selected by using cluster random sampling technique. The technique of analyzing data used was independent sample-T-test and effect size. The result of data analysis showed that there is a significant difference on students' reading comprehension of narrative texts taught without and by using the Puppet Show Strategy, in which the Sig (2-tailed) 0.000 had less value than 0.05 . Thus, $\mathrm{H}_{\mathrm{a}}$ is accepted and $\mathrm{H}_{\mathrm{o}}$ is rejected. Furthermore, there is a significant effect of using the Puppet Show strategy on the students' reading comprehension of narrative texts of the eighth grade at Islamic Junior High School Al-Muttaqin Pekanbaru, in which the result of eta squared 0.285 was bigger than 0.21 , thus, it was categorized into "modest effect". This research concluded that teaching reading comprehension by using Puppet Show strategy to the eighth grade students of Islamic Junior High School AlMuttaqin Pekanbaru was better than students who were taught without using Puppet Show strategy, thus, this research recommended other researchers to conduct the better research by developing the other kinds of puppet as the media in teaching learning processes.
\end{abstract}

Keywords : Effect, Puppet Show Strategy, Reading Comprehension 


\section{Introduction}

Reading is a crucial need of students to master English well. It is called receptive process; since it is receiving the words without producing the words (Johnson, 2008). In accordance with the statement above, Patel and Jain (2008) stated that reading is not only a source of information and a pleasurable activity but also as means of consolidating and extending one's knowledge of the language. In short, reading is very important for expanding someone's knowledge and finding information

Reading was not only difficult at Islamic Junior High School Al-Muttaqin Pekanbaru, but also in other educational levels. In line with the statement above, Dorn and Soffos (2005) revealed that reading is a complex process involving a cognitive point of view working together for making meaning. Regarding the previous idea, Murcia (2001) said that the readers' expectation after reading a written text is to make a meaning and to comprehend what they read. Dealing with that statement, as one of the expectations of the readers in reading something, the comprehension involves word knowledge (vocabulary), prior knowledge and readers' engagement to construct meaning in the text (Pang et al., 1986). Concisely, an ultimate goal of reading is comprehension. Thereby, the comprehension can be told as the core of reading activities.

Meanwhile, in order to accomplish the students' need on reading, the SchoolBased Curriculum provides reading as one of the skills in English mastery that must be taught and learned in Islamic junior high school. Based on BSNP (2006, p.128) the goals of teaching reading can be seen as follows:

a. Responding meaning in a simple and short functional written text accurately, fluently, and acceptably enabling them to interact in daily contexts.

b. Responding meaning and rhetorical steps in a simple short essay accurately, fluently, and acceptably enabling them to interact in daily context in the forms of written descriptive, recount, and narrative.

Islamic Junior High School Al-Muttaqin is one of the formal education institutions in Pekanbaru applying School Based Curriculum as its guidance in teaching and learning process. In Islamic Junior High School Al-Muttaqin Pekanbaru, there are 2 professional English teachers there, Mrs. Petti S.Pd and Miss Mutia Herfina S.Pd. English had been taught starting form seventh grade. It is taught twice a week with time duration about $2 \times 45$ minutes. Based on the syllabus of the 2016/2017 the standard competences demand the students to respond to the meanings and the rhetorical pattern of a simple short narrative and recount texts accurately and fluently related to the environment while the basic competences demand the students to understand the meanings of a short functional text and a simple essay organizing narrative and recount for interacting with the surrounding environment. Furthermore, the minimum the students passing grade $(\mathrm{KKM})$ is 75 .

Based on the preliminary study of the writer at Islamic Junior High School Al-Muttaqin Pekanbaru on March, $12^{\text {th }} 2016$ by interviewing the English teacher and the eighth grade students, the writer found that reading comprehension (narrative texts) had been taught by implementing School Based Curriculum that was summarizing strategy. It was taught based on 
standard competence and basic competence of reading.

Theoretically, according to Silver (2007) the summarizing requires the students to make decisions about what content that is essential and nonessential, sorts information into meaningful sets, and communicates their ideas cohesively. Then, Duffy (2009) also mentioned that the summarizing strategy can be used to help students to identify the internal structure of a story (narrative text).

During activities, the teacher gave explanation about narrative texts, asked the students to read the text and identified the generic structure of narrative texts, then asked the students to summarize the text, asked the students to tell about what they read, explained about the content of narrative texts, asked the students to answer the questions about the narrative texts, and then made conclusion of the lesson and closed the learning session. From the descriptions above, the students had been taught well starting from seventh grade by professional English teachers. Ideally, those efforts were effective enough for helping the students in improving their reading comprehension skills.

However, the students seemed not to perform their reading comprehension well. It could be seen from the students' score, there were only $10(31 \%)$ students who could pass the minimum students passing grade (KKM) scores while 22 (69\%) students could not pass the minimum students passing grade (KKM) scores, thus, the students had limited understanding to identify the specific information, generic structures, language features, communicative purposes and references.

Therefore, referring to the instability scores of the students based on the standard of the minimum students passing grade (KKM), the writer proposed the Puppet Show strategy, notably paper puppets in order to edify the students' teaching process. The paper puppets are simple to be made and modified by adding some colorful things and it is interesting for the students.

Furthermore, teaching reading comprehension by using puppet show strategy empowers students in learning process and develops students 'reading comprehension skills (Bennet, 2002). Furthermore, According to Overholt (2010) the use of puppets was explored students' comprehension while reading a variety of texts. The students will focus intently on the puppets, maintain high levels of concentration and they will be especially motivated to read (Keogh, 2006). It is clear that the use of puppets can motivate student in comprehending reading selection or topic (Nurhayati, 2011).

Referring to the descriptions stated above, the objectives of the research were want to investigate whether there is or no significant difference on students' reading comprehension of narrative texts taught without and by using the Puppet Show Strategy and whether there is or no significant effect of using the Puppet Show strategy on the students' reading comprehension of narrative texts of the eighth grade students of Islamic Junior High School Al-Muttaqin Pekanbaru.

\section{Research Method}

The type of this research was experimental research, notably a quasi-experimental design. As pointed by Lodico et al. (2006) the quasi-experimental design involves random assignment of whole classes rather than individuals to treatments, thus, there were two variables used in this research; they were independent variable $(\mathrm{X})$ and dependent variable (Y). In this research, the independent variable (X) was Puppet Show 
strategy and dependent variable (Y) was students' reading comprehension of narrative texts. In conducting this research, two classes of the eighth grade students at Islamic Junior High School Al-Muttaqin Pekanbaru were participated.

This research was conducted at Islamic Junior High School Al-Muttaqin Pekanbaru, Riau. It was located on Jalan H.R Soebrantas Pekanbaru. This research was conducted on September 2016.

The subject of this research was the eighth grade students of Islamic Junior High School Al-Muttaqin Pekanbaru. The object of this research was the effect of using Puppet Show strategy on students' reading comprehension of narrative texts.

The population of the research was the eighth grade students at Islamic Junior High School Al-Muttaqin Pekanbaru. They consisted of four classes. The total number of population was 123 students. The researcher used cluster random sampling technique in determining the sample of the research. As pointed out by Lodico et al. (2006) cluster random sampling is a procedure of selecting classes randomly and it is not allowed by selecting individually.

In this research, the writer took the classes by using lottery. The writer made the paper rolls, and then selected it randomly. The first selection referred to experimental class while the second referred to control class. Then, two classes chosen were VIII A as experimental class and VIII $\mathrm{B}$ as control class, and the total of them were 64 students.

Furthermore, the procedures of using Puppet Show strategy can be seen as follows (Bennet, 2002):

a. The teacher divides the students into groups consisting of 4 students.

b. The teacher distributes the reading text and the puppets. Then, she asks the students to discuss and read the text.

c. After getting the puppets, the students have some questions and ask the teacher about it. Then the teacher allows and appreciates it.

d. The teacher tells a story based on the text given by using puppet.

e. The teacher tells the students the purposes of puppet show performances.

f. The teacher asks the students about the text given.

g. Then the students tell the text by using their own words and puppets in front of the classroom.

\section{Technique of Collecting Data}

In completing the data, the writer used techniques of collecting data, namely observation and test. The observation was done by getting the data about the implementation of the Puppet Show Strategy on students' comprehension of narrative by presenting a table consisting of procedures of Puppet Show strategy, observation times and total. In this research, the writer analyzed the result of observational list data by using formula to get the percentage of the observation (Sudijono, 2007, p.43):

$$
\mathbf{P}=\frac{\mathbf{F}}{\mathbf{N}} \mathbf{X} 100 \%
$$

Where: P : Percentage

$F$ : Frequency of the score

$\mathrm{N}$ : Number of Case

In the other hands, the tests were used for collecting the data on the effect of using of Puppet Show strategy on students' reading comprehension of narrative texts. The type of the tests was multiple choice tests related to narrative texts. There were twenty five questions given to the students. The questions were based on the indicators of reading narrative texts. Before the tests were given to the samples, the tests were tried out in order to obtain validity 
and reliability of the tests. It was determined by finding the difficulty level of each item. Furthermore, the tests were composed of 25 items, and each item was given score 4. The final score was analyzed by using the following formula (Sudijono, 2008, p.32):

$$
=\frac{\text { total correct answers }}{\text { total number of questions }} \times 100
$$

\section{Technique of Analyzing Data}

Observation was used in order to investigate whether or not the strategy used had been applied as well as the procedure or not and to collect the data about the implementation of using Puppet Show strategy. The writer had a list of observational item observed in experimental class during the teaching and learning process.

The writer used the following formula to get the percentage of the observation (Sudijono, 2007, p.43):

$$
\mathbf{P}=\frac{\mathbf{F}}{\mathbf{N}} \mathbf{X} 100 \%
$$

Where P: Percentage

$\mathrm{F}$ : Frequency of the score

$\mathrm{N}$ : Number of Case

$\mathrm{F}$ Yes $=37 \quad \mathrm{~F} \mathrm{No}=5$

$\mathrm{P}_{\text {Yes? }}$ ? And $\mathrm{P}_{\text {No }}$ ?

$\mathrm{P}_{\text {Yes }}=\frac{37}{42} \times 100 \%$

$=88 \%$

$\mathrm{P}_{\text {No }}=\underline{5} \times 100 \%$

42

$=12 \%$

From the result above, it can be seen that the Puppet Show strategy was successfully implemented for $88 \%$ while the percentage of failure was $12 \%$

The data of reading comprehension taught without using the Puppet Show Strategy were obtained from pre-test and post-test scores of VIII B as the control class. It was analyzed by using statistic software of Statistical Product and Service Solutions (SPSS) 22 version. It can be presented in the following table:

Table 1

Score Classification of Control Class Students' Post-test

\begin{tabular}{cccc}
\hline Categories & Score & Freq & Percentage \\
\hline Very & $80-$ & 3 & $9.4 \%$ \\
Good & 100 & & \\
Good & $66-79$ & 10 & $31.3 \%$ \\
Enough & $56-65$ & 13 & $40.6 \%$ \\
Less & $40-55$ & 6 & $18.8 \%$ \\
Fail & $30-39$ & - & \\
& Total & & $\mathbf{1 0 0 \%}$ \\
\hline
\end{tabular}

Referring to the table above, the majority of the control class students' post-test scores were classified into "enough" category.

Besides, the mean and standard deviation are also needed in analyzing data which were gotten from the score of pre-test and posttest. It can be seen as follow:

Table 2

The Statistic of Pre-test and Posttest Scores

\begin{tabular}{lcc}
\hline & $\begin{array}{c}\text { Post-Test } \\
\text { Score }\end{array}$ & $\begin{array}{c}\text { Pre-Test } \\
\text { Score }\end{array}$ \\
N Valid & 32 & 32 \\
$\quad$ Missing & 32 & 32 \\
Mean & 64.8750 & 64.5000 \\
Median & 64.0000 & 64.0000 \\
Std. Deviation & 11.07089 & 11.07161 \\
Sum & 2076.00 & 2064.00 \\
\hline
\end{tabular}

Based on the table viewed above, it can be illustrated that the mean of pre-test of control class was 64.5000 and post-test was 64.8750; while the standard deviation of pretest of control class was 11.07161 and post-test was 11.07089 .

Furthermore, the data of reading comprehension taught by using the Puppet Show Strategy were 
taken from the pre-test and post-test scores of VIII A as the experimental class. It can be illustrated in the following table:

Table 3

\begin{tabular}{cccc} 
Score Classification of Experimental & $\begin{array}{c}\text { Class Students' } \\
\text { Post-test }\end{array}$ \\
\multicolumn{4}{c}{} \\
\hline Categories & Score & Freq & Percentage \\
\hline Very & $80-$ & 13 & $40.6 \%$ \\
Good & 100 & & \\
Good & $66-79$ & 16 & $50 \%$ \\
Enough & $56-65$ & 3 & $9.4 \%$ \\
Less & $40-55$ & - & \\
Fail & $30-39$ & - & \\
& Total & & $\mathbf{1 0 0 \%}$ \\
\hline
\end{tabular}

Based on the table above, the majority of the control class students' posttest scores were classified into "good" category.

Moreover, the mean and standard deviation were also needed in analyzing data gotten from the score of pre-test and post-test. It can be illustrated as follow:

Table 4

The Statistic of Pre-test and Post-test Scores

\begin{tabular}{lcc}
\hline & $\begin{array}{c}\text { Post-Test } \\
\text { Score }\end{array}$ & $\begin{array}{c}\text { Pre-Test } \\
\text { Score }\end{array}$ \\
N Valid & 32 & 32 \\
$\quad$ Missing & 32 & 32 \\
Mean & 76.8750 & 65.6250 \\
Median & 76.0000 & 64.0000 \\
Std. Deviation & 8.72427 & 7.72825 \\
Sum & 2460.00 & 2100.00 \\
\hline
\end{tabular}

Referring to the table presented above, it can be seen that the mean of pretest of experimental class was 65.6250 and post-test was 76.8750; while the standard deviation of pre-test of experimental class was 7.72825 and post-test was 8.72427 .

Before going to investigate the significant difference of using Puppet Show strategy on students' reading comprehension of of the eighth grade students at Islamic Junior High School AlMuttaqin Pekanbaru, the writer analyzed the mean and standard deviation of experimental and control classes in the following table:

Table 5

The Differences between the Students' Post-test scores in Experimental and Control Classes

\begin{tabular}{|c|c|c|c|}
\hline & $\mathbf{N}$ & $\begin{array}{c}\text { Mean } \\
\text { Statistic }\end{array}$ & $\begin{array}{c}\text { Std. } \\
\text { Deviation } \\
\text { Statistic }\end{array}$ \\
\hline Experimental & 32 & 76.8750 & 8.72427 \\
\hline Control & 32 & 64.5000 & 11.0716 \\
\hline $\begin{array}{l}\text { Valid N } \\
\text { (listwise) }\end{array}$ & 32 & & \\
\hline
\end{tabular}

From the table presented above, it was clear that the total number of the students from each class was 32. The mean scores of experimental and control classes were 76.8750 and 64.5000. The standard deviations of experimental and control classes were 8.72427 and 11.07161. Therefore, the mean and standard deviation of post-test scores for both experimental and control classes were significantly different.

Moreover, before doing independent sample t-test analysis, the writer needed to analyze and test the hypotheses pre-requisite test as the first analysis containing and homogeneity and normality tests making sure the experimental and control classes were homogenous and normally distributed by using SPSS software.

The result of homogeneity testing can be seen as follow:

Table 6

The Homogeneity of the Data

\begin{tabular}{|c|c|c|c|c|}
\hline & $\begin{array}{l}\text { Levene } \\
\text { Statistic }\end{array}$ & df1 & df2 & Sig. \\
\hline $\begin{array}{l}\text { Based on } \\
\text { Mean }\end{array}$ & 1.259 & 1 & 62 & .266 \\
\hline $\begin{array}{l}\text { Based on } \\
\text { Median }\end{array}$ & 1.175 & 1 & 62 & .283 \\
\hline $\begin{array}{l}\text { Based on } \\
\text { Median }\end{array}$ & 1.175 & 1 & $\begin{array}{c}59.0 \\
03 \\
\end{array}$ & .283 \\
\hline
\end{tabular}


and with

adjusted

df

Based on

trimmed

1.250

1

62

mean

Referring to the table showed above, it was clear that the probability (sig) based on trimmed mean was $(0.266>0.05)$, thus, the data were homogenous variance.

In term ofthe result of normality testing, it can be seen as follow:

Table 7

The Normality of the Data

\begin{tabular}{|c|c|c|c|c|c|c|}
\hline & \multicolumn{3}{|c|}{$\begin{array}{l}\text { Kolmogorov- } \\
\text { Smirnov }^{\mathrm{a}}\end{array}$} & \multicolumn{3}{|c|}{ Shapiro-Wilk } \\
\hline & $\begin{array}{l}\text { Statisti } \\
\text { c }\end{array}$ & df & Sig & $\begin{array}{l}\text { Statisti } \\
\text { c }\end{array}$ & df & Sig \\
\hline $\begin{array}{l}\mathbf{E} \\
\mathbf{x}\end{array}$ & .134 & 32 & .15 & .962 & 32 & .30 \\
\hline $\begin{array}{l}\text { C } \\
\mathrm{t}\end{array}$ & .138 & 32 & .12 & .964 & 32 & .35 \\
\hline
\end{tabular}

Based on the table showed above, it was clear that the significant level in Kolmogorov-Smirnov test of post-test in experimental and control classes were $(0.15>0.05)$ and $(0.12>0.05)$. It means that $\mathrm{H}_{\mathrm{o}}$ was accepted while $\mathrm{H}_{\mathrm{a}}$ was rejected. In other words, the both data were normally distributed. Therefore, the writer used independent sample t-test.

Furthermore, the output SPPSS of independent sample t-test can be illustratd in the following table:

Table 8

Independent Sample T-test

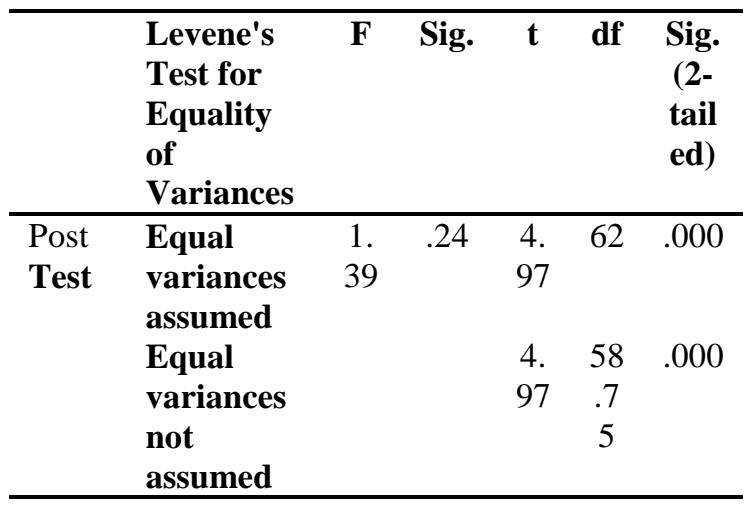

The table above showed that that $\mathrm{H}_{\mathrm{o}}$ was rejected and $\mathrm{H}_{\mathrm{a}}$ was accepted because the probability sig. (2-tailed) was 0.000 less than 0.05 .

Besides, the output SPSS of eta squared showed that 0.285 , it was bigger than 0.21 , thus, it can be categorized as "modest effect" level.

\section{Research Findings}

Based on research findings, the students' reading comprehension taught without using Puppet Show strategy of the eighth students at Islamic Junior High School AlMuttaqin Pekanbaru was categorized into "enough" level. The students' reading comprehension taught by using Puppet Show strategy of the eighth students at Islamic Junior High School Al-Muttaqin Pekanbaru was categorized into "good" level. There was a significant difference on students' reading comprehension of narrative texts taught without and by using the Puppet Show Strategy of the eighth grade students at Islamic Junior High School Al-Muttaqin Pekanbaru. There was a significant effect of using the Puppet Show strategy on the students' reading comprehension of narrative texts of the eighth grade students at Islamic Junior High School Al-Muttaqin Pekanbaru.

\section{Concluding Remarks}

Based on finding as already discussed above, the writer concluded that teaching reading comprehension by using Puppet Show strategy to the eighth grade students of Islamic Junior High School Al-Muttaqin Pekanbaru was better than students who were taught without using Puppet Show strategy. 
Hopefully, this research is expected to be used and useful as starting points to conduct the better research by developing the other kinds of puppet as the media in teaching learning processes.

Finally, the writer considers that the Puppet Show strategy can be used in other schools to investigate the effect of the strategy used in teaching reading. It can also be a relevant research for the other researchers.

\section{References}

Bennett, R. (2002). Teaching Reading with Puppets. Canada: Unpublished.

Dorn, L. J \& Carla S. (2005). Teaching for Deep Comprehension. A Reading Workshop Approach. Portland: Stenhouse Publishers.

Duffy, G. G. (2009). Explaining Reading. A Recourse for Teaching Concepts, Skills, and Strategies. Seccond ed. London: The Guildford Press.

Johnson, A. P. (2008). Teaching Reading and Writing. A Guidebook for Tutoring and Remediating Students. United States of America: Rowman and Littlefield Education.

Murcia, M. C. (2001). Teaching English as a Second or Foreign Language. Third ed,. United States of America: Heinle \& Heinle.

Silver, H. F et al,. (2007). The Strategic Teacher. Selecting the Right Research-Based Strategy for Every Lesson. The United States of America: Association for Supervision and Curriculum Development.

Keogh, B., et al,. (2006). Puppets Bringing Stories to Life in Science. London:
Millgate House Education Ltd.

Lodico, M. G et al. (2006). Methods in Educational Research.

From Theory to Practice. San Francisco: Jossey-Bass.

Nurhayati, D. (2011). "The Effectiveness of Using Hand Puppet to Improve Students Speaking Skills in Performing Adjacency Pairs. An Experimental Study of Seventh Graders of SMP 11 Semarang in the Academic Year of 2011/2012. Unpublished.

Overholt, K. (2010). "The Incorporation of Puppetry Into Reading Instruction". Education and Human Development Master's Theses Journal: Unpublished.

Pang, S. E et al., (1986). Teaching Reading. Switzerland: The International Academy of Education (IAE).

Patel, M. E., \& Praveen, M. J. (2008). English Language Teaching. Jaipur: Sunrise Publishers \& Distributors.

Sudjiono, A. (2007). Pengantar Statistik Pendidikan, Jakarta: PT. Raja Grafindo Persada. 